\title{
THE COMMON AGRICULTURAL POLICY: FROM QUANTITY TO QUALITY?
}

\author{
Joseph A McMahon, Professor of International Trade Law, \\ Queen's University Belfast
}

\section{INTRODUCTION}

Opening a High Level Round Table on Food Quality in March this year, David Byrne, the Commissioner for Health and Consumer Protection, noted that the goal of food security has been realised. He continued: ${ }^{1}$

“. . . general affluence and surplus in our food supply has resulted in a gradual change in public policy focus away from efficiency and productivity towards quality and diversity in agri-food production. Indeed modern food production methods themselves have raised matters of public concern beyond human health and safety in relation to environmental and ethical aspects of agri-food production. .."

He went on to suggest the need for a new food production/consumption model, which would be focussed on food safety and food quality. This debate has arisen out of a concern for the future of European agriculture in the wake of the BSE crisis and more recently, the outbreak of foot and mouth in the United Kingdom.

Other factors will influence this debate, not the least of which are the possible renegotiation of the Uruguay Round Agreement on Agriculture and the probable enlargement of the European Union (EU) to include the countries of Central and Eastern Europe. As for when further reform will occur many dates can be suggested. The mid-term review of the Agenda 2000 reforms will occur in 2002, the peace clause of the Agreement on Agriculture expires in 2003, the next Inter-Governmental Conference will be held in 2004, enlargement may become a reality by 2005, and the Berlin Summit set the end-date for the current reforms as 2006.

Irrespective of which date is chosen, the policy will be subject to further reform and, consequently the Common Agricultural Policy (CAP) may pursue different objectives. In all previous reforms, the objectives of the policy as enshrined in Article 33 of the Treaty of Rome have never been changed. Two questions arise:

\footnotetext{
Inaugural Lecture delivered 8th November 2001, Queen's University Belfast. I would like to express my thanks to David Capper for his decision to restore the practice of publishing Inaugural lectures in the Quarterly. Thanks must also go to Dr John Davis of the Department of Agriculture and Food Economics at Queen's University Belfast and to Professor Alan Matthews of the Department of Economics at Trinity College Dublin for their comments on the Inaugural Lecture.

1 See http://www.europa.eu.int/comm/dgs/health_consumer/library/speeches/ speech88_en.html.
} 
- why have past reforms not led to a re-writing of the objectives of the policy?

- $\quad$ if the objectives are to be re-written, what objectives will be pursued by the EU and the Member States in the area of agriculture and rural policy?

This lecture will address these two questions, however, before doing so, it is necessary to examine the objectives set for the CAP, especially as interpreted by the European Court of Justice.

\section{The Objectives of the CAP}

The objectives set for the CAP in Article 33 EC (ex Article 39) are:

1. (a) to increase agricultural productivity by promoting technical progress and by ensuring the rational development of agricultural production and the optimum utilisation of the factors of production, in particular labour;

(b) thus to ensure a fair standard of living for the agricultural community, in particular by increasing the individual earnings of persons engaged in agriculture;

(c) to stabilise markets;

(d) to assure availability of supplies;

(e) to ensure supplies reach consumers at reasonable prices.

2. In working out the common agricultural policy and the special methods of its application, account shall be taken of:

(a) the particular nature of agricultural activity, which results from the social structure of agriculture and from structural and natural disparities between the various agricultural regions;

(b) the need to effect the appropriate adjustments by degrees;

(c) the fact that in the Member States agriculture constitutes a sector closely linked with the economy as a whole.

The objectives are a reflection of the three factors that have always been used to justify governmental intervention in the agricultural sector: ${ }^{2}$

- the politico-economic factor, i.e. to contribute to overall economic growth of the Member States, both individually and collectively,

- the socio-political factor, i.e. a concern with the welfare of the rural population,

- the socio-economic factor, i.e. a concern with adequate food supplies for consumers.

2 See A. El-Agraa, The Economics of the Common Market (4th edition) (Harvester Wheatsheaf, London, 1994) pp 211-12, and J. Marsh and P. Swanney, Agriculture and the European Community (Allen \& Unwin, London, 1980) pp 12-16. 
Looking more closely at the objectives, the first objective to be pursued in Article 33(1), an increase in agricultural productivity, is to be pursued by promoting technical progress and a rational development and optimum use of agricultural production factors. This implies a type of regional structural policy, an implication which is given added weight by Article 33(2)(a) which requires the particular nature of agricultural activity to be taken into account in the working out of the policy. Using the word "thus" in paragraph (b) it appears that both objectives are connected. Therefore, it could be argued that the regional structural policy must lead to an achievement of a fair standard of living for the agricultural community. However, some doubt can be cast on this interpretation because of the second part of paragraph (b), which sets as an objective, an increase in the individual earnings of persons engaged in agriculture. This may mean that the most important aspect of the objectives is to increase the earnings of agricultural producers so that they have a fair standard of living, thus making paragraph (b) a type of income guarantee. As such, it would have to be achieved over the longer term. In contrast, paragraph (c) is more interested in the short-term effects of fluctuations in prices, demand and supply. The policy must therefore include mechanisms designed to smooth out these fluctuations, thereby connecting paragraph (c) with paragraph (d), although no reference is made to techniques which would ensure such availability of supplies or to the scope of Community activity in this area. Finally, paragraph (e) confirms that the scope of the policy is not to be limited to producers and processors but is to extend to consumers. Prices for them are to be "reasonable" as opposed to the standard of living of farmers, which is to be "fair".

Turning from the literal approach to Article 33(1) to the jurisprudence of the European Court of Justice on the separate objectives of the CAP, the range of possible approaches to the future development of the policy may be identified. For example in the Danske Landboforeninger case, the Court pointed out that: ${ }^{3}$

... the very wording of Article 39(1) shows that the increase in the individual earnings of persons engaged in agriculture is envisaged by being primarily the result of the structural measures described in sub-paragraph (a).

The Court has also declared that Article 33(1)(b) does not constitute an income guarantee for farmers. ${ }^{4}$

With respect to the remaining objectives of Article 33(1), the Court has held that a range of measures may be used to stabilise markets. ${ }^{5}$ Measures to effect such stability which impact adversely on individuals, do not give that individual the right to complain. ${ }^{6}$ In relation to the safeguarding of supplies there are no fixed mechanisms to achieve this. Finally, with respect to paragraph (e), the Court made it clear in the case of Germany v Commission that reasonable prices did not mean the lowest possible prices but had to be

3 Case 297/82 [1983] ECR 3299, p 3317. See also cases 36 and 71/80 Irish Creamery Milk Suppliers Association [1981] ECR 735.

4 See for example, case 2/75 Mackprang [1975] ECR 607 and case 281/84 Bedburg [1987] ECR 49.

5 Case 250/84 Eridania [1986] ECR 117 and case 46/86 Romkes [1987] ECR 2687.

6 Cases 63-69/72 Wehrhahn [1973] ECR 1229. 
considered in the light of the CAP. ${ }^{7}$ In a later case, the Court would rule that Article 33 would only be breached if a measure led to consumer prices that were obviously unreasonable. ${ }^{8}$

No hierarchy of objectives is indicated in Article 33(1) but it is obvious that the CAP has a series of objectives that are both conflicting and not capable of reconciliation. As early as 1968, the Court recognised that the Community institutions would have to balance the competing demands of Article 33(1). ${ }^{9}$ The classic formulation of this balancing act occurred in the case of Balkan, where the Court stated: ${ }^{10}$

"In pursuing these objectives the Community institutions must secure the permanent harmonisation made necessary by any conflict between these aims taken individually and, where necessary, allow one of them temporary priority in order to satisfy the demands of the economic factors or conditions in view of which their decisions are made."

The formulation has been repeated by the Court on several occasions with the Court limiting itself to an examination of whether the measure in question contains a manifest error, constitutes a misuse of power or whether the discretion enjoyed by the Community institutions has been exceeded. ${ }^{11}$

With respect to the Balkan formula, it must be pointed out that it in conflict with the Court's approach to the interpretation of Article 2 of Regulation 26/62, where an agreement hoping for exemption from the competition provisions must satisfy all the objectives of the CAP. This is demonstrated by the decision in FRUBO. ${ }^{12}$ Secondly, the statement suggests that at some stage the Court may overrule a measure of the institutions if the situation of "temporary priority" is continued for a substantial period, thus jeopardising the achievement of the other objectives of the policy. The possibility that the Court could adopt such an approach was highlighted in its decision in Behla-Mühle. ${ }^{13}$ The Court in this case declared a regulation on the compulsory purchase of skimmed milk powder, which was designed to reduce stocks of this product that had increased significantly, to be null and void. In doing so, the Court used the objectives in Article 33(1), the rule on non-discrimination contained in Article 34(3), and the general principle of proportionality to rule that the obligations imposed by the regulation were discriminatory and not necessary to attain the objectives of the CAP. One further interesting feature of the case, arising from the current reforms of the

7 Case 34/62 [1963] ECR 131.

8 Case 5/73 Balkan [1973] ECR 1091.

9 Case 5/67 Beus [1968] ECR 83, where the Court stated that: "As those objectives are for the protection of agricultural producers as well as of consumers, they cannot all be realised simultaneously and in full."

10 Supra $\mathrm{n} 8, \mathrm{p} 1112$.

11 See for example, case 29/77 Roquette Frères [1977] ECR 1835, case 203/86 Spain $\checkmark$ Council [1988] ECR 4563, and case C-311/90 Hierl [1992] ECR I-206. See also the repetition of the Balkan formula by the Court of First Instance case T-489/93 Unifruit Hellas [1994] ECR II-1201.

12 Case 71/74 [1975] ECR 563. See also case C-399/93 Oude Luttikhuis [1995] ECR $\mathrm{I}-4515$.

13 Cases 114, 116 and 119-20/76 [1977] ECR 1211. 
CAP, was the suggestion by Advocate General Capotorti that a strict interpretation of Article 33(1) might: ${ }^{14}$

. . . justify the conclusion that the whole of the market policy so far followed by the Community is illegal in view of the fact that ... its essential basis is the fixing of prices to suit agricultural products in order to assure farmers an adequate income, whereas the policy favouring the modernisation and structural improvements and, in consequence, the rational development of agricultural production has been late in gathering momentum and is now evolving slowly and with considerable difficulty.

Whilst the Community institutions enjoy considerable discretion in the implementation of a policy to achieve the objectives of Article 33(1), both individually and collectively, it is important to conclude that the discretion is not unlimited. Considerable latitude has been given to the institutions by the Balkan formula but as Behla Mühle indicated there are limits to that latitude. The limits were hinted at in Crispoltoni II where after repeating the Balkan formula the Court continued: "That harmonisation must preclude the isolation of any one of those objectives in such a way as to render impossible the realisation of other objectives." 15

It must be acknowledged that Article 33 is not the only relevant provision when it comes to establishing the objectives of the CAP. According to Article 3(e), a common policy in the sphere of agriculture is one of the mechanisms available to the Community institutions for achieving the general objectives of the Treaty. ${ }^{16}$ The Court has made it clear, for instance, that the objectives set by Article 33 cover all aspects of agricultural production from public health and consumer protection to animal welfare issues. ${ }^{17}$ Moreover, the interpretation advanced by the Court allows the scope of the CAP to expand to embrace new policy goals identified within the Treaty, such as environmental regulation in Article 174 or development co-operation in Article 177. ${ }^{18}$ The only restrictions imposed by the Court are that the measures adopted must concern agricultural products as defined by

14 Ibid p 1229. See also case C-353/92 Greece v Council [1994] ECR I-3411, involving a challenge to Regulation 1765/92 (OJ 1992 L 181/12) where the Court accepted that stabilising markets can take precedence over a fair income for farmers in certain circumstances.

15 Joined cases C-133/93, C-300/93 and C-362/93 [1994] ECR I-4863, p 4903. See also joined cases 197-200, 243, 245 and 247/80 Ludwigshafner Walzmühle [1981] ECR 3211 for a similar statement.

16 See for example, case 48/74 Charmasson [1974] ECR 1383, cases 80 and 81/77 Ramel [1978] ECR 927, and case 68/86 UK v Council (Hormones) [1988] ECR 855 .

17 On public health and consumer protection see for example, case 11/88 Commission v Council (Pesticides) [1989] ECR 379, case C-146/91 KYDEP [1994] ECR I-4199, and case C-180/96 United Kingdom v Commission [1998] ECR I-2265; on animal welfare see case 131/86 UK v Council (Battery Hens) [1988] ECR 905 and case C-27/95 Woodspring [1997] ECR I-1847.

18 See case C-280/93 Germany v Council [1994] ECR I-4973, where the Court rejected the German argument that the regulation establishing the common organisation of the market in bananas was part of a development policy for the CAP and so could not be based on Article 37 (ex Article 43). 
Annex II of the Treaty and that the measure is intended to achieve one or more of the objectives of Article 33. ${ }^{19}$

\section{Past Reforms of the CAP}

In December 1960, the Council made their first substantive decision on the CAP, thus paving the way for the introduction of that policy. The significance of that decision rests with its establishment of the three basic principles of the CAP; common prices, common financing, and Community preference. ${ }^{20}$ In the years that followed, common organisations were gradually introduced so that by the end of the transitional period common organisations existed for the bulk of the products listed in Annex II. A single Guidance and Guarantee Fund (known by its French acronym, FEOGA) was introduced in 1962 and split into two separate sections in 1964; a Guarantee section to finance the prices and markets policy and a Guidance section to finance structural operations. Only in the early 1970s did the Community institutions seriously address the need to reform the structure of European agriculture through a reappraisal of the structural policy. The original principles were designed to meet the situation where Europe was still a net importer of agricultural products. The support of farm incomes through internal price arrangements and the partial or total exclusion of imports of certain products because of increased protection at the frontiers of the Community ensured that the policy met the problems it was initially designed to deal with. However, once this situation had been reached, the instruments of the policy were not changed. Therefore surpluses appeared in a number of areas, with a consequent negative impact on prices, and trade relations with third countries deteriorated with increases in the level of Community subsidised exports and continuing restrictions on imports.

Reform of the policy was inevitable. Such reform, according to the Commission in 1980, would have to reconcile four main objectives: ${ }^{21}$

(1) to maintain the positive aspects achieved, i.e. consumer security of supply, income of farmers, free trade and the contribution of farming to external trade;

(2) to set up mechanisms whereby the budgetary consequences of production surpluses may be held in check. This could be achieved by adjustment of market organisations to introduce the principle of co-responsibility or producer participation;

(3) to ensure better regional distribution of the benefits derived by farmers from the CAP; this would entail a radical readjustment of structural policy aimed at the reduction of regional disparities; and,

19 See for example, case 68/86 United Kingdom v Council [1988] ECR 855 and case 11/88 Commission v Council [1989] ECR 379. On the interpretation of Annex II, see Cases 2 \& 3/62 Commission v Belgium and Luxembourg [1962] ECR 425, case 185/73 König [1974] ECR 607, case 77/83 CILFIT [1984] ECR 1257, and case 123/83 BNIC v Clair [1985] ECR 391

20 Bull. CE 1/61, p 83.

21 COM (80) 800 Reflections on the Common Agricultural Policy. 
(4) to organise the financing of the CAP on sound foundations which will not cause disputes in future between Member States.

Gradual reforms were introduced throughout the 1980s and, to a limited extent, they met the objectives set by the Commission in the above statement. For example, on the introduction of mechanisms to check the budgetary consequences of surplus production, it is possible to point to the introduction of milk quotas in $1984 .{ }^{22}$ Further confirmation of the emergence of a fourth principle, producer responsibility, would emerge in 1986 and 1987 as limits were imposed on market support for cereals and milk products. In 1988 further stabilisation measures were introduced in all market organisations and also in 1988, the European Council agreed to place an overall ceiling on agricultural expenditure, linking it to trends in the Community's GDP. Reform of structural policy later in 1988 constituted an attempt to ensure a better regional distribution of the benefits derived from the CAP.

These reforms represented the beginning of a process of continuing reform of the CAP. Further reforms emerged in 1992 with the so-called "MacSharry reforms". In essence, these reforms were two-fold. Firstly, there was a threeyear reduction in the level of prices in the arable crops and beef sectors. The purpose of such a reduction was to bring the level of Community prices closer to those on the world market, so improving the competitiveness of Community production. The negative impact of such price reduction on the income of farmers was mitigated by the introduction of compensatory payments. Various premia were payable to all farmers on the basis of eligible acreage and a set-aside premium was also payable on land that had been withdrawn from production. Likewise in the beef sector compensatory payments were introduced and were made payable based on a maximum stocking rate per hectare. The second set of reforms built on the compensatory payments by introducing a range of accompanying measures, such as the granting of aid to farmers to encourage the protection of the environment, the landscape and natural resources. These latter reforms would be built on as a consequence of the reference in the Maastricht Treaty to rural areas in the context of the economic and social cohesion of the Community. They would also allow the Community to build on the 1988 reforms of the structural funds that had encouraged integrated rural development.

As for an assessment of these reforms, it must be pointed out that they were limited to those areas where the budgetary and international trade problems had become most acute; other areas such as sugar were excluded, as such problems had not arisen. So the 1992 reforms were not a wholesale reform of the CAP, rather a response to both internal and external problems. This raised some doubt as to what was likely to happen in other sectors of the policy, where the problems were not so prominent, in the years that would follow. As was usual the Commission's reform proposals were more dramatic than the end result; the original proposals had called for a $40 \%$ reduction in cereal prices but the final figure was $29 \%$. Having said this,

22 See G. Avery, "The Common Agricultural Policy: A Turning Point" (1984) 21 CMLRev 481. 
agreement on such a large cut did represent a significant shift in the attitudes of the Member States and a symbol of the future direction of the CAP. As for the nature of the symbol, it was clear, especially concerning the conditions attached to the set-aside provisions, that the burden of financing agricultural expenditure was being shifted from the consumer to the taxpayer. One commentator concluded: ${ }^{23}$

"They have failed to address the fundamentally objectionable features of the CAP and they have introduced a new and unwelcome policy instrument into the CAP's operations. They have not addressed the distortions the CAP creates, they leave decision making capacity in the hands of institutions that have demonstrated their incapacity to make good decisions, and they even appear unlikely to have solved the budgetary problems that first put reform on the EC agenda."

Coupled with these reforms, agreement was reached in 1994 in the Uruguay Round of multilateral trade negotiations, including for the first time an Agreement on Agriculture that would establish legally binding commitments in the areas of market access, domestic support and export subsidies. Parties to the Agreement would be expected to increase market access, through tariff reductions and the adoption of the process of tariffication for existing nontariff barriers. The level of support offered by domestic agricultural policies would be calculated and reductions would have to be made in certain areas. Aspects of such policies were categorised in terms of boxes, with the MacSharry reforms being placed in the Blue Box - the result of the Blair House Accord. Finally, budgetary restraints and quantitative limitations would be placed on export subsidies. This Agreement also provided for the introduction of a further Agreement on Sanitary and Phytosanitary Measures and for stronger and more operationally effective GATT rules. The Uruguay Round Agreement and the new GATT rules would be policed by the newly created World Trade Organisation (WTO) which would enforce the rules through the newly effective dispute settlement process. The Agreement on Agriculture, the overall activities of the WTO and its Dispute Settlement Body, would accentuate the impact of the 1992 reforms, and emphasised the need for further reform of the policy.

In its assessment of the MacSharry reforms the 1997 Agenda 2000 document noted both a considerable improvement of market balances and continuing improvements in average agricultural incomes. But the reforms had had mixed effects on the environment and had led to increased budgetary expenditure in the sectors affected by the reforms. The reforms were characterised as insufficient to meet the new demands confronting the CAP in the years to come, of which the Commission identified three distinct, but inter-related, problems. The first problem was the adaptation of the existing policy to maintain the Community's position in world trade. An element of that adaptation would involve the re-negotiation of existing international commitments and the negotiation of new commitments and this was recognised as the second problem. The final problem was the adoption of the new policy (accompanied by consequential reforms) by the applicant countries of Central and Eastern Europe on their accession to the

23 M. Atkin, Snouts in the Trough (Woodhead Publishing, 1993), p 146. 
Community. Any one of these problems represents a significant challenge to the Community.

The initial Commission thinking on the nature of the reforms needed in the CAP was outlined in the Agenda 2000 document itself. It involved a "deepening and extending" of past reforms through a further package that would convert the primary support mechanism of the CAP from price support to direct payments accompanied by a more aggressive rural policy. The latter was needed not only to implement a more coherent policy to tackle the social and economic problems of rural areas but also to reinforce and enhance the existing environmental aspects of those areas and the CAP. This particular aspect of rural policy was seen as increasingly demanded by the citizens of the Union, who at the same time, in their capacity as consumers, were also demanding greater food safety and products which were both "environmentally-friendly" and "culturally-significant". In addition to these objectives, the new CAP would also demand the promotion of greater economic and social cohesion between the Member States.

In March 1998 more detailed proposals for the reform of the CAP were published by the Commission, which were intended to translate the above reforms into legal texts. ${ }^{24}$ These proposals envisaged:

- the role of intervention would be to act as a safety net for farmers rather than as a guarantee of price stability.

- to ensure a fair standard of living for the farmers affected by these changes, the direct payments introduced in 1992 would be increased.

- a new division of functions between the Community and the Member States. For example, in the area of direct payments to producers, a limited amount of compensation would be provided in the form of national envelopes by the Community, with the Member States being responsible for the allocation of this money, subject to agreed criteria, to its agricultural producers. As examples of the agreed criteria, a degressive ceiling was proposed on the amount of direct aid that a farm could receive and Member States would be able to adjust the direct aids awarded on criteria they defined relating to the number of workers employed on a farm.

- a similar decentralised approach was also to be taken in the area of rural development, where there would be two groups of measures, constituting a kind of second pillar to the CAP. First, those relating to less favoured areas and the measures in the 1992 reform package such as early retirement, and agri-environment measures, would be co-financed by the Community through the FEOGA Guarantee section for all regions of the Community. The second group of measures, relating to modernisation and diversification would be financed as part of the Community's efforts to promote greater economic and social cohesion in the Community in the newly defined Objective 1 and Objective 2 areas.

${ }^{24}$ COM (98) 158. This publication can also be found on the Directorate-General for Agriculture's website. 
In the aftermath of the publication of the Commission proposals considerable discussion occurred between the Member States on the scope of the reform of the CAP. In preparation for the European Council in Berlin in March 1999, the Council eventually reached a political agreement on a compromise package of reforms. ${ }^{25}$ As for the elements of the reform package, the intervention price for arable crops was to be cut by $20 \%$ in two steps starting in 2000/2001, and to compensate farmers for the loss of income, direct payments were to be increased. As for other measures, compulsory set aside was to be retained with the basic rate to be set at $10 \%$ for the two marketing years beginning in 2000 but was to be reduced to $0 \%$ as from 2002; the system of voluntary set aside was to be maintained and improved. In the beef sector, the price reduction was also set at $20 \%$ to be achieved by three equal steps; when the final step was taken a basic price for private storage of beef would be established as would a "safety-net" intervention system. Once again, as compensation for the price reductions payments under various premia would be increased subject to various regional ceilings. As a measure to promote flexibility, various national envelopes were established allowing Member States to compensate producers for regional variations in production practices and conditions.

The political agreement on reforms to the arable crops and beef sector followed the proposals advocated by the Commission with important changes, notably the price reduction in the arable crop sector was to be $20 \%$ over two years rather than the one year proposed and price reduction in the beef sector was to be $20 \%$ rather than the $30 \%$ advocated. This pattern would be repeated in the reforms agreed in the milk sector. As for measures applicable to all common organisations of the market, there was broad agreement within the Council on the proposals advanced by the Commission, although significantly the proposal to impose ceilings on direct payments was not endorsed. In relation to rural development policy, the Council endorsed the Commission's proposals for a more coherent and sustainable rural development policy, which would create a stronger agricultural and forestry sector and would be more competitive and respectful of the environment and the rural heritage.

Overall, although less ambitious than the original proposals of the Commission, the political agreement on reforms represented an attempt by the Council to continue with the reform process initiated by the MacSharry reforms. However, the agreement still had to be endorsed by the European Council, as it was only one part of the Agenda 2000 package of reforms. In welcoming the political agreement of the Council, the European Council commented that: ${ }^{26}$

The content of this reform will ensure that agriculture is multifunctional, sustainable, competitive and spread throughout Europe, including regions with specific problems, that it is capable of maintaining the countryside, conserving

25 See European Commission Directorate-General for Agriculture Newsletter 11 (Special Edition) Agriculture Council: Political Agreement on CAP Reform (Brussels, 1999).

26 Presidency Conclusions Berlin European Council, Part I A. Heading 1 (Agriculture) 2 (available on Europa website). 
nature and making a key contribution to the vitality of rural life, and that it responds to consumer concerns and demands as regards food quality and safety, environmental protection and the safeguarding of animal welfare.

Despite this welcome, various changes were made to the political agreement on reform. ${ }^{27}$

For example, the agreed changes to the dairy regime, save those on quotas, were not to enter into force until the marketing year 2005/2006 and the intervention price for cereals, instead of being reduced by $20 \%$, was to be reduced by $15 \%$ with the base rate of compulsory set aside to be fixed at $10 \%$ for all of the period 2000-2006. Beyond these changes the Council and the Commission were requested to pursue additional savings, except in the areas of rural development and veterinary measures, to ensure that average annual agricultural expenditure over the period 2000-2006 would not exceed 40.5 billion Euros. It was considered by the European Council that the reform of the CAP over this period, along the lines agreed by the Council, as amended by the European Council, would lead to a reduction in expenditure, thus contributing to the overall objective of achieving a more equitable financial framework. One aspect of the latter objective was agreement on another major aspect of the Agenda 2000 reform package - structural operations - where there would be three programmes, thus matching the number of Objective Areas. ${ }^{28}$ Additional funding for rural development would also be available under the agricultural aspect of the financial perspective, which indicates that financing for rural development and accompanying measures shall not exceed an average of 4340 million Euro over the period 2000-2006.

The overall agreement on the Agenda 2000 package reached at the Berlin European Council undoubtedly represented an important milestone for the CAP and for the Community. As for the nature of that milestone, several points may be made. Reform of the policy up to this time had concentrated on the three (or four) core principles established for the policy in 1960. Although the MacSharry reforms added a more effective second pillar to the CAP, they did not fundamentally alter the fact that the CAP was a price support and production control policy. With the changes to the role of intervention, an increasing emphasis on direct payments and greater support for rural policy, the Agenda 2000 reforms signalled a further realignment of the twin pillars of the CAP towards a situation of greater equilibrium. Although the objectives set for the policy in Article 33 can accommodate this realignment, just as all past extensions of the scope of the CAP have been accommodated, the Agenda 2000 reforms also signalled greater scope for national discretion in rural development regulation and in the implementation of the national envelopes. Although falling short of a partial renationalisation of the policy, the fact that the next Inter-Governmental

27 See European Commission Directorate-General for Agriculture Newsletter 10 Berlin European Council: Agenda 2000, Conclusions of the Presidency (Brussels, 1999).

28 Supra n 26, Heading 2 (Structural Operations). As for the three schemes, these included the INTERREG scheme on cross-border and inter-regional co-operation and the LEADER scheme on rural development. 
Conference (IGC), to be convened in 2004, will discuss regional rights and responsibilities may signal further moves in this direction. ${ }^{29}$

\section{New Objectives?}

The Commission has listed five particular objectives as motivating its proposals for reform of the CAP: ${ }^{30}$

- to increase competitiveness;

- to assure food safety and food quality;

- to maintain a fair standard of living for the agricultural community and stabilise farm incomes;

- to better integrate environmental goals into the CAP; and

- to develop alternative job and income opportunities for farmers and their families.

For the Commission, such objectives would confirm the nature of the European model of agriculture as being multifunctional. How would such objectives be achieved?

In November 1995, the Directorate-General for Agriculture invited a group of experts to analyse the inconsistencies and problems inherent in the existing CAP and in this light to define a series of principles that would form the basis of a new integrated rural policy. The resulting report, known as the Buckwell report, proposed that the existing CAP should be transformed into a Common Agricultural and Rural Policy for Europe (CARPE) whose objective would be "to ensure an economically efficient and environmentally sustainable agriculture and to stimulate the integrated development of the Union's rural areas." 31 The three elements of the new policy, economic efficiency, the environment and rural development, would, unlike the CAP, be equally balanced. The report made it clear that the new policy, although revolutionary, would also be evolutionary, so allowing the policy to respond to new challenges as they emerge.

As for the first element of the new policy, economic efficiency, the goal would be to reduce the level of price support to world market levels, with the role of the Community being to provide a safety net in the forms of intervention. There is no doubt that the MacSharry and the Agenda 2000 reforms have reduced the level of price support within the Community and the Agenda 2000 reforms, when fully implemented, will begin the process of returning intervention to its proper role as a safety net. However, a number of problems remain. With respect to the probable enlargement of the Community, in relation to direct support there are no proposals for the abolition of this form of support or for their conversion into truly decoupled payments. This raises the prospect of the acceding countries receiving

29 See Declaration 23 attached to the Treaty of Nice. Paragraph 5 of this declaration on the future of the Union states that the debate to be launched in 2001 will, inter alia, address the question of how to establish and monitor a more precise delimitation of powers between the European Union and the Member States, reflecting the principle of subsidiarity.

30 COM (99) 22 Directions towards Sustainable Agriculture, p 30.

31 See europa.eu.int/en/comm/dg06/new/buck_en/index.htm, chapter 6.1 
"compensation" for losses that they have not suffered, and assumes they have the same rights and duties with respect to agriculture as the existing Member States. Secondly by agreeing to lesser price reduction than originally proposed and by delaying in some cases actual price reductions, the Agenda 2000 reforms add to the cost of enlargement. A more radical reduction in prices and the end to the use of existing direct support measures would have the advantage of opening the Community market to greater imports as the isolation of that market is ended. This would allow the Community to participate effectively in the next round of international trade negotiations on agriculture, as the support that it provides would be decoupled. There are two particular areas to be examined here, market access and domestic support

In relation to market access, the Agreement on Agriculture provided for the usual reduction in tariffs and the conversion of existing non-tariff barriers into tariffs, the process of tariffication. Although the agreement on tariffication was significant, the impact of that process has not been. One reason for this is the choice of base period, 1986-88, when the difference between world and domestic prices was particularly high. Another reason is that several WTO members have engaged in the process of "dirty tariffication" - the setting of tariff equivalents in excess of the price differential for that period. ${ }^{32}$ Consequently, many tariffs contain what is referred to as "a good deal of water" allowing for their subsequent reduction without adversely affecting domestic prices. When combined with the Special Safeguard Provision in Article 5 of the Agreement on Agriculture, the net result is that there has not been a significant increase in market access for a number of WTO members. The Community has been one of the guilty parties here. Indeed, the Agenda 2000 reforms did not lower import tariffs, thus increasing the amount of "water" in its tariff. ${ }^{33}$

In recognition of the likely marginal impact of the market access commitments, the Agreement on Agriculture provides for a range of minimum access tariff quotas (5\% of $1986-88$ consumption levels by 2000 , if 1986-88 imports fell short of this amount). Such quotas have again proved problematic, not least because they lack transparency. It is no surprise, therefore, that major reform of such quotas is high on the agenda of the current discussions. Even the Community has proposed that a set of rules and disciplines should be defined to increase the transparency, the reliability and the security of the management of Tariff Rate Quotas, so that concessions granted should be fully realised. ${ }^{34}$ Beyond this, it has proposed the retention of Article 5, the special safeguard clause, and measures: ${ }^{35}$

“ (a) to guarantee effective protection against usurpation of names for agricultural products and foodstuffs;

32 See Ingco, "Tariffication in the Uruguay Round: How much Liberalisation?" (1996) 19(4) The World Economy 425.

33 See Swinbank, "CAP Reform and the WTO: Compatibility and Developments" (1999) 26(3) European Review of Agricultural Economics 389, pp 396-99.

34 See WTO document G/AG/NG/W/90 - EC Comprehensive Negotiating Proposal, paragraphs 2-4.

35 Ibid, paragraphs 18-19. See also G/AG/NG/W/18 - Food Quality: Improvement in Market Access Opportunities. 
(b) to protect the right to use geographical indications or designations of origin; and

(c) to guarantee consumer protection and fair competition through regulation of labelling."

To enable the Community to achieve these non-trade concerns may require additional concessions in the area of market access. At least the Community has provided itself with room for manoeuvre in this area.

The existing Community position on domestic support in the negotiations for a new Agreement on Agriculture does not envisage the abolition of the Blue Box, indeed such payments are seen as an important tool in further agricultural reform and so the concept of the Blue Box would be retained. ${ }^{36}$ Most WTO members do not envisage the retention of this exceptional measure, and envisage changes in the nature of the Aggregate Measurement of Support (AMS). For example, it has been suggested that the new Agreement should introduce product-specific limits on support rather than having the AMS calculated for the entire agricultural sector. Such a change, effectively repealing the Blair House Accord, would generate significant problems for the Community.

More immediately, additional problems in the Blue Box may also be generated as a result of the Agenda 2000 reforms. Under Article 13 of the Agreement on Agriculture, during the implementation period, which ends in 2003 , limited protection is provided to Blue Box measures that conform fully to the provisions of Article 6(5) and where no determination of injury or threat thereof is shown. According to Article 6(5)(a) direct payments under production-limiting programmes will be exempt from the domestic support reduction commitment if:

(i) such payments are based on fixed areas and yields; or

(ii) such payments are made on 85 per cent or less of the base level of production; or

(iii) livestock payments are made on a fixed number of head.

In the Agenda 2000 document and the March 18 proposals, the Commission went to great lengths to create a "virtual cow" as the basis for compensating farmers for the reduction in the level of support prices for milk. Such a payment could have come within Article 6(5)(a)(iii). However, the premium eventually agreed was based on the farmer's milk quota, and, as a result, is unlikely to come within the scope of Article 6(5). At least, the European Council set the base rate of compulsory set aside at $10 \%$ for the period 20002006, rather than at 0 as recommended by the Commission, thus ensuring that the policy could appear to be production-limiting.

Rather than promote competitiveness, it seems clear that the Community is intent on maintaining the Blue Box as an integral element of the CAP. Such a policy will be dependent on the continuation of Article 13 of the Agreement on Agriculture. As for the future of this provision, some countries envisage a new Peace Clause that ensures that they would not be challenged so long as they comply with their commitments on export

36 See in particular, G/AG/NG/W/17 - EC Proposal on Domestic Support. 
subsidies and domestic support under the Agreement. For others, the new Agreement would contain no new Peace Clause, as this would frustrate their overall objective of bringing agriculture under general WTO disciplines. Some countries have proposed variants. ${ }^{37}$ The conclusion is that, given few WTO members actually use the Blue Box ${ }^{38}$ the Community may have to pay heavily for its retention and the protection provided by Article 13, even if it is prolonged, is very limited. An approach that would promote the objectives identified by the Commission as motivating the Agenda 2000 reforms and which would not be as problematic internationally merits consideration. Such an approach would eschew continued reliance on the Blue Box in favour of policy objectives that could be pursued legitimately under the Green Box of the Agreement on Agriculture.

One of the legitimate public policy objectives to qualify as a Green Box policy, the protection of the environment, formed the second aspect of the proposed CARPE. Environmental and Cultural Landscape Payments would be made for positive action taken by farmers. This was defined as the provision of services that impose an additional cost on farmers. The payments would be regionally based and there would be two levels of payments. The first level would be directed to farming systems providing high nature value whilst the second level would concern specific environmental management practices, such as intensive action to preserve or create significant environmental effects. The distinction between the two levels rested in the fact that level one was directed at farming whereas level two was directed at the environment, although there would be some crossfertilisation between the two levels.

With respect to the Green Box, the Community's negotiating position recognises the need to retain the Green Box, which is viewed as including measures that meet important societal goals such as the protection of the environment and the sustained vitality of rural areas. ${ }^{39}$ However, the position advocates a re-assessment of the criteria used for Green Box measures so as to ensure that such measures are well-targeted, transparent and cause minimal trade distortion. One problem that has not yet surfaced in relation to the Green Box is the criterion that support provided by such policies should have a minimal impact on production. Again, it emerges from Article 13 of the Agreement on Agriculture which affords protection, during the implementation period, to Green Box measures that conform fully to the provisions of Annex 2. The protection is limited, as Annex 2 requires Green Box measures must have a minimal impact on production. This raises two questions: ${ }^{40}$

37 For example, Canada would like to see "green box" domestic supports freed from the possibility of countervailing action under the Subsidies Agreement. (G/AG/NG/W/92) India proposes something like the Peace Clause should be retained but only for developing countries, so that some subsidies are free from the possibility of countervailing duty. (G/AG/NG/W/102)

38 See the Memorandum of the Australian Government in House of Commons, CAP Reform: Agenda 2000. Volume II. Second Report from the Agriculture Committee 1997-98 Session HC 311-11 (HMSO, London, 1998).

39 Supra n 34, paragraphs 13-16

40 See Blandford, "Are Disciplines Required on Domestic Support" (2001) 2(1) The Estey Centre Journal of International Law and Trade Policy 35, p 48. 
(a) if payments are made whose primary aim or effect is to increase producer incomes, will these payments have a minimal impact on production?

(b) if payments are made to achieve other aims, e.g. environmental objectives, is it logical to require these to have a minimal impact on production?

Any payments made will increase the funds available to the producer for use in his/her business, so it will have an impact on production. It will also have an impact on the other less obvious outputs of agriculture - this is the multifunctionality argument. With respect to the generation of employment, it would be more rational to allocate resources to rural development as a means of generating rural employment. As for the protection of the rural landscape, the payment will necessarily have an impact on production - for example supporting particular production methods - and of necessity on trade. Clearer criteria, as the Community itself has recognised, are needed for all Green Box payments. The problem here for the Community is that existing policy measures under the second pillar of the CAP may not fully conform to Annex 2. For example, there are no clear environmental criteria used in the payment of various premiums, neither are they limited to those farmers in the less-advantaged areas of the Community. The Environmental and Cultural Landscape Payments recommended by the Buckwell Report are much more in accordance with the existing criteria of Annex 2 of the Agreement on Agriculture.

These payments, according to the Buckwell Report, would form part of the third aspect of the proposed new CARPE, Rural Development Incentives. Rural development would remain wider than agricultural development and the approach would involve a continuation of the existing policy of promoting sustainable rural development. So the existing measures of assistance directed towards agricultural development would continue. Given the major changes involved in the transition from the CAP to the CARPE, the report recommended the transformation of the compensation payments introduced in the 1992 reform package into what is termed Transitional Adjustment Assistance. The three principles of such assistance are that it will be decoupled from production, be non-distorting of competition, and that recipients should respect environmental conditions. It is worth noting that the proposed objectives of the Commission are met to a greater extent by the proposed CARPE than by the Agenda 2000 reforms. Market stabilisation measures would increase the competitiveness of European agriculture. Equally, the Environmental and Cultural Landscape Payments and the Rural Development Incentives would maintain a fair standard of living for the agricultural community and stabilise farm incomes, whilst better integrating environmental goals into the CAP and developing alternative job and income opportunities for farmers and their families.

The Commission's policy, supported by the Council and the European Council, is much more problematic. It involves continued reliance on an instrument whose future is uncertain, the Blue Box, and whose continued existence may require significant sacrifices to be made by the Community. Moreover, the Agenda 2000 reforms have actually increased the possibility of a WTO challenge to existing measures. Article 13 of the Agreement on Agriculture provides only limited immunity from such challenges. Existing 
policy with respect to the environmental aspects of the CAP is also not immune from challenge in the WTO. The approach of the Community to the negotiations for a new Agreement on Agriculture has been to stress the balance between trade and non-trade concerns. In order to promote future liberalisation and expansion of international agricultural trade, which will contribute to economic growth in all countries, the Community claims that: ${ }^{41}$

“. . . it is vital to muster strong public support, which can only be achieved if other concerns are met, in particular the multifunctional role of agriculture, which covers the protection of the environment and the sustained vitality of rural communities, food safety and other consumer concerns including animal welfare."

The objective for the Community is WTO recognition of the multifunctional role of agriculture. The problem for the Community is that the objectives of the CAP do not afford recognition of that multifunctionality.

\section{CONCLUSION}

One element of whether or not it is appropriate to re-write the objectives of the CAP may be determined this year as the Commission assesses the impact of the Agenda 2000 reforms. Speaking at a conference in Dublin, Franz Fischler, the Commissioner for Agriculture, suggested that the future of the CAP rested with consumers. ${ }^{42}$ He continued by noting that the mid-term review of Agenda 2000 may be viewed as the "ideal opportunity for all the stakeholders to contribute to the future orientation of a genuinely European agricultural policy." At present, what is envisaged is a further strengthening of the second pillar of the CAP, the rural development policy. However, this may not be enough, after all the pursuit of the objectives of the CAP has led to mounting concerns about human health and safety, and the environmental and ethical aspects of agricultural production.

If the argument being advanced is that the objectives of the CAP have been realised, especially in the area of food security, then should the new food production/consumption model have new objectives? Equally, if the Community is seeking WTO recognition of the multifunctional role of agriculture then should the objectives of the CAP not recognise that multifunctionality?

The key to this concept is the contribution that farming makes to a series of societal goals or non-trade concerns. Two points must be emphasised here. First, to be acceptable it must be shown that the net contribution made by agriculture is greater or more valued by society than the net contribution of equivalent sectors. Only when this can be shown will assistance to agriculture be seen as worthy of continued government assistance as opposed to other sectors that do not receive assistance, yet contribute to societal goals. It is here that evidence is particularly difficult to determine. For example, is there a difference between general product safety and food safety? Is there something culturally significant about food and farming which merit especial

41 Supra n 34, para 1.

42 Speech "Agriculture and Agri-Food: A clean green future" available on Rapid (DN: Speech/01/254), Dublin 31 May 2001. 
attention? The argument of the Community is that there is a difference with respect to food and that there is a European model of agriculture. The second point is that price support is not the appropriate mechanism to promote the multifunctionality of agriculture. There will have to be a rebalancing of the existing pillars of the CAP in favour of the second pillar. So, the protection of the environment would be a part of the broader Community environmental policy. The focus of the existing environmental aspect of the CAP needs to reflect concern with the environment rather than being used as a means to supplement farmer's income. Payments must become truly decoupled. The "sustained vitality of rural communities" would be a part of the Community policy to promote economic and social cohesion. Farmers would be seen as part of the rural community but it must be acknowledged that the policy of price support is a blunt instrument to support that community. A more regionalised approach to rural development is needed.

The European model of agriculture, and the means to realise it, must be included within the Treaty. The existing objectives do not reflect what is being characterised as "the European model of agriculture." Moreover, it is unlikely that they can provide a sufficient basis for a new production/consumption model. To emphasise the nature of the changes to the existing objectives, the new objectives should place the consumer first through an emphasis on food safety and food quality. The means to achieve this objective include existing mechanisms promoting such areas as organic production, geographical indicators and animal welfare issues. Other existing areas would be re-focussed, for example, greater use of instruments to support environmentally sound production methods. Such instruments would be environmentally based rather than producer based. Moving to the producer, payments would be made, sufficient to ensure a fair standard of living, on the basis of the contributions made to the societal goals recognised in the European model of agriculture, for example, the cultural landscape. In addition, the farmer would be seen as part of the rural community and mechanisms would be devised to promote the economic and social cohesion of such communities.

The Buckwell report concluded:43

"From its origins, when the CAP was most definitely part of the big European political and cultural compromise assistance for agriculture to adjust, in return for an open market for industrial products - it has descended into [a] purely commodity approach. In this process it lost its sense of purpose. A bold new start towards a more integrated rural policy could reassert a constructive role for this important aspect of the European Union."

Considerable political capital has been invested in the CAP throughout the history of the Community. However, a time has been reached when the objectives of the policy are no longer appropriate to the model of agriculture that consumers are demanding. Coupled with the concerns of consumers, the international environment in which the policy operates is fundamentally

43 Supra n 31, Chapter 8.5. 
different from that of the 1950s. A new set of objectives must be drawn up, especially if the Community wishes to defend successfully in international negotiations what it has labelled the "European model of agriculture." A debate on the future objectives of the policy should be launched as a result of the mid-term review of the Agenda 2000 reforms and the 2004 IGC offers an ideal opportunity to realise a new set of objectives for the policy. These objectives would be more regionally and environmentally oriented than the existing objectives and would place the consumer at the heart of an integrated agricultural and rural policy. A common policy at European level would continue to exist but, respecting the principle of subsidiarity, would increase regional rights and responsibilities, as direct assistance to farmers would be tailored to the needs of each region. Such new objectives would represent a bold new start for the CAP and re-establish its constructive role within the European Union. 